\title{
Adolescent Disability, Post-16 Destinations, and Early Socioeconomic Attainment: Initial Evidence from Next Steps
}

1. Sanne Velthuis, University of Warwick \& University of Manchester

2. Stella Chatzitheochari, University of Warwick

\begin{abstract}
Recent decades have witnessed a dramatic increase in the prevalence of adolescent disability. However, research on the life-course transitions and trajectories of disabled adolescents remains sparse. This working paper addresses the lack of longitudinal evidence surrounding school-to-work transitions of disabled young people in England. We analyse longitudinal data from Next Steps in order to provide a descriptive analysis of post16 transitions and early socioeconomic attainment of disabled young people in England. Our analysis moves beyond existing studies by examining the whole range of post-16 destinations, and by exploring variation between different disability categories wherever possible. We also examine whether disability differentials in post-16 destinations and economic activity in early adulthood vary by social class, ethnicity, and gender, highlighting opportunities for intersectional analyses. Overall, our results show substantial disability differentials in post-16 destinations. We find that disabled young people are less likely to stay in post-16 education and more likely to experience unemployment compared to nondisabled peers. Results reveal inequalities in the type of post-16 education young people follow too, with disabled cohort members more likely to be in general Further Education colleges and less likely to attend school sixth forms and sixth form colleges, as well as university, compared to students with no long-standing limiting conditions and/or learning difficulties. We find pronounced disability gaps in young people's main activity at age 25, documenting variations by other social divisions. We also outline avenues for future research on adolescent disability and social inequality.
\end{abstract}

\section{Acknowledgements}

This research was funded by the Leverhulme Trust Research Project Grant Educational Pathways and Work Outcomes of Disabled Young People in England (RPG-2020-202). 


\section{Introduction}

Recent decades have witnessed a dramatic increase in the prevalence of adolescent disability (Halfon et al. 2012). The association of adolescent disability with socio-economic disadvantage has been well-documented by previous research: disabled young people are more likely to come from disadvantaged backgrounds (Blackburn, Spencer, and Read 2010), and tend to lag behind non-disabled peers in educational, occupational, and social outcomes in adulthood (Chatzitheochari and Platt 2019; Janus 2009; Parsons and Platt 2020; Shandra and Hogan 2009). However, sociological accounts of inequality continue to largely neglect disability as a social division, while social stratification research on lifecourse transitions and trajectories of disabled adolescents remains sparse. As a result, we still know little surrounding the societal processes that lead to disability differentials in educational and occupational attainment.

It could be argued that this limited empirical interest is partly a result of commonly held medical understandings of adolescent disability that view educational and occupational disadvantage as caused by impairments and conditions themselves, failing to take into account the vast heterogeneity within constructed disability categories (Powell 2003). At the same time, data availability constitutes an important barrier for researchers interested in childhood and adolescent disability: Research on this group is typically constrained by cross-sectional and/or non-generalizable samples that do not include non-disabled peers as a base of comparison (Shifrer 2013). Most importantly, there is a lack of nationally representative longitudinal datasets that provide sufficient numbers of disabled young people for analysis, alongside measures that capture different factors and processes likely to influence key socioeconomic outcomes. Consequently, only a handful of studies have examined the effect of disability status and type of disability on the educational and occupational attainment of young people longitudinally (Chatzitheochari and Platt; Janus 2009; Shandra and Hogan 2009; Shifrer and Freeman 2021).

Large-scale evidence on the educational and work outcomes of disabled youth comes mainly from the US (Champaloux and Young 2015; Crump et al. 2013; Janus 2009; Joshi and Bouck 2015). There is less quantitative research from the UK, where the majority of studies focus on the educational progress and outcomes of younger children with special educational needs who receive additional teaching support in inclusive settings (for example, see Crawford and Vignoles 2010; Parsons and Platt 2017). As a result, less is known about the transitions and socioeconomic outcomes of young people with disabling conditions, especially those who do not receive official school recognition but still face substantial educational and social barriers (Chatzitheochari, Parsons, and Platt 2016).

At the same time, studies that examine transitions following the end of compulsory schooling tend to focus on "successful" and "unsuccessful" destinations, that is, securing a university place or becoming NEET, neglecting those following other pathways in the "middle" (Gayle, Murray, and Connelly 2014). For example, recent research examined educational transitions of disabled young people using Next Steps data (Chatzitheochari and Platt 2019), particularly focusing on those who successfully completed key educational transitions, from GCSE to university entry. However, this research did not examine 
destinations of those who do not achieve $5 A^{*}$-C GCSE grades, which account for approximately 3 out of 4 disabled young people in England.

Research on adolescent disability has also paid little attention to its interplay with different axes of inequality, an issue raised in several theoretical accounts of disability (Jenkins 1991; Shifrer and Frederick 2019). Such a focus can further challenge monolithic and reductionist accounts of disability as individual pathology (Liasidou 2012) by highlighting the influence of other ascriptive characteristics on the life transitions and trajectories of disabled adolescents. While the relationship of race and special educational needs status has attracted considerable attention in the sociology of education literature in the UK (Tomlinson 2017), less is known about the interaction of social class and gender with different types of adolescent disability with regards to different socioeconomic outcomes.

Taking into account these gaps in existing research, our aim is to provide an initial descriptive analysis of post-16 destinations and early socioeconomic attainment of disabled young people in England. We focus on a relatively recent cohort of young people who completed their compulsory schooling in July 2006 and have already entered the labour market. This allows us to provide novel evidence surrounding socioeconomic attainment of disabled young people in early adulthood. We also document disability differentials in occupational attainment and occupational status. Disability differentials have not been considered by previous research focusing on school-to-work transitions of the same cohort (Dickerson, Morris, and McDool 2020). Finally, we examine whether post16 destinations and economic activity outcomes of disabled young people vary by social class, ethnicity, and gender, highlighting opportunities for intersectional analyses in disability research. We also outline avenues for future research on adolescent disability and social stratification. 


\section{Methodology}

\subsection{Next Steps Data}

We analyse data from Next Steps, formerly known as the Longitudinal Study of Young People in England (LSYPE). Next Steps is a nationally representative youth cohort survey consisting of approximately 16,000 adolescents born in 1989-1990 from secondary schools in England (University College London, Institute of Education, and Centre for Longitudinal Studies 2021). The cohort was interviewed annually from age $13 / 14$ to age 19/20 (Waves 1 7), and at age 25 (Wave 8). Cohort members and their parents/guardians provided information on topics surrounding schooling and education, family environment, and socioeconomic circumstances. The study can also be linked with administrative educational records, which provide direct measures of students' academic performance (GCSE, A Levels etc.). Next Steps predominantly captures young people in mainstream rather than special schools (Chatzitheochari and Platt 2019).

Next Steps is the most recent cohort survey that can be used to document school-to-work transitions of disabled adolescents in England: Participants of the Millennium Cohort Study and LSYPE2 have not yet completed school-to-work transitions. However, we acknowledge that the transition to the labour market is a longitudinal process that is not fully complete by age 25 and we also emphasize that this cohort's transition to adulthood coincided with an economic recession, which should be kept in mind when interpreting results presented in this paper.

\subsection{Adolescent Disability Measures}

Next Steps included disability measures in two separate sections of the parent/guardian questionnaire in Wave 1.

Parents/guardians were asked whether the young person has a long-standing illness, condition, or impairment. Those who answered yes were then asked two follow-up questions as to whether school attendance or ability to complete schoolwork is affected by the illness/condition. We can thus identify disabled young people as those whose longstanding conditions limit school attendance or ability to complete schoolwork, which is line with theoretical understandings of childhood and adolescent disability (Altman 2014). These young people are referred to as having a long-standing limiting illness (LSLI).

Parents/guardians were also asked whether the cohort member is currently thought to have special educational needs (SEN) of any kind. If so, they also reported whether the young person has a "statement" of special educational needs, which outlines the additional teaching support they receive at school. It should be kept in mind that having special educational needs does not necessarily entail cognitive deficits. Rather, the SEN population is particularly heterogeneous, consisting of students with varying social, ethnic, linguistic, physical, and intellectual disadvantages (Powell 2006). Having a statement of need is often regarded as an indicator of severity of SEN (Parsons and Platt 2020) and is typically associated with lower academic performance compared to other broad disability groups (Chatzitheochari, Parsons, and Platt 2016). However, it should be 
noted that statements of need also render students more susceptible to stigmatization and "othering" in the school context (Holt 2004), which may in turn have a negative impact on educational attainment. Parents/guardians were also asked about the young person's type of need. For this analysis, we did not consider young people whose parents/guardians only reported "English as second language" as their need as having special educational needs (Chatzitheochari and Platt 2019).

Although Next Steps also collected information on type of long-standing limiting illness (Wave 1), it is not feasible to use measures of type of disability/special educational need in our analyses due to small sample sizes in several subgroups, which are further reduced by sample attrition. In addition to this, the analytical focus on specific conditions has been criticized for implicitly locating disadvantage within the individual in line with the medical model of disability (Chatzitheochari and Platt 2019). However, we acknowledge that physical, cognitive, and socio-emotional disabilities are subject to different structural and cultural "ableisms" (Campbell 2009) that can in turn have different implications for lifecourse transitions and trajectories. Unfortunately, it is not possible to reliably categorize students by these broad groups of conditions/disabilities in the analysis.

We define as disabled all young people who have LSLI, or SEN, or both, as measured at wave 1. There is substantial overlap between LSLI and SEN groups in Next Steps, with 54\% of those with LSLI also reported as having SEN in Wave 1. We argue that overlaps in parental reports may indicate conditions more likely to hinder learning and influence schooling experiences. Our analysis thus makes use of a nested 4-category disability status variable: 1) not disabled, 2) disabled, LSLI only, 3) disabled, with SEN (no statement) 4) disabled, with SEN statement. The "disabled with SEN (no statement)" and the "disabled, with SEN statement" categories contain all those identified with and SEN in the study, including those who also have LSLI.

The same set of questions was asked to parents in Wave 2. We thus use Wave 2 information for the small number of young people (approximately 4 per cent of the Wave 1 sample) with missing values on the disability variables in Wave 1.

\subsection{Post-16 Destinations Measures}

In order to document young people's destinations after the end of compulsory schooling, we examine self-reported main activities over a period of two-and-a-half years, from November 2007 to May 2009. Captured in Waves 4, 5, and 6 of Next Steps, this period covers the three academic years following Key Stage 4 (when students sit their GCSEs). During this period young people can be observed in a number of activities, ranging from education and paid employment to unemployment. While young people could report engagement in multiple simultaneous activities (for example, combining education with a part-time job), Next Steps used a number of questions to determine the main/primary activity for cohort members.

There are slight differences between activity categories across different waves of the study. We therefore harmonized activity categories over the two-and-a-half year period that we are focusing on. The activity categories we use are: 
1) education

2) employment (either full- or part-time ${ }^{1}$ )

3) apprenticeship or training

4) unemployment, and

5) other

The "other" category includes all activities that do not fit in the other 4 categories, such as looking after the home or family, taking a break from studying, waiting for a course or job to start, and travelling.

Rather than focusing on the main activity young people were engaged in at the time of each interview, we used information on timing of activities to be able to measure activities at fixed points in time, namely November and May of each academic year. This provides us with six time-points at which we observe the main activities of cohort members. This strategy allows us to overcome inconsistency problems arising from the length of the fieldwork period, which resulted in some sample members being interviewed when they had just finished (or were at the very end of) the previous academic year, others during the summer months, and others at the start of the next academic year.

The first time-point that we examine is November after completion of Key Stage 4. For young people who move on to sixth form after year 11, this will be usually referred to as "year 12". We use this terminology as a shorthand to denote the different time-points of our analysis, although we recognize that not all young people will be in sixth form, or even education, following Key Stage 4.

The six time-points are:

- November of year 12 (i.e. a few months into the first academic year following Key Stage 4)

- May of year 12 (i.e. towards the end of the first academic year following Key Stage 4)

- November of year 13 (i.e. a few months into the second academic year following Key Stage 4)

- May of year 13 (i.e. towards the end of the second academic year following Key Stage 4)

- November of year 14 (i.e. a few months into the third academic year following Key Stage 4)

- May of year 14 (i.e. towards the end of the third academic year following Key Stage 4)

\footnotetext{
${ }^{1}$ Most cohort members reporting employment as their main activity are in full-time employment. Among those who are in part-time employment, the majority work at least 8 hours per week.
} 


\subsection{Post-16 Education Provider Measures}

The vast majority of young people move into some sort of education following Key Stage 4. Next Steps provides information on the type of education provider attended by young people at each of the six time points examined in our analysis. However, information on type of education provider is only gathered from young people who were in education at the time of their interview. We are thus unable to determine type of education provider for those young people who dropped out of education between the time-point in question (e.g. November of year 12) and the date of the subsequent Next Steps interview. Information about type of education provider is missing for 4 to 22 per cent of the weighted sample depending on the time-point. This information is slightly more likely to be missing for disabled young people in the study. In order to overcome this issue, we examine type of education provider attended in May of each academic year rather than in November. This is because May is closer in time to the date of each wave's fieldwork, resulting in a smaller proportion of young people who experienced a change in activity in the intervening period.

We are able to identify 5 different categories of education providers: 1 ) School (maintained or independent), 2) Sixth Form College, 3) General Further Education College, 4) Specialist College (e.g. Agricultural college), 5) Other. The 'Other' category includes Academies, City Technology Colleges, and similar providers.

\subsection{Socioeconomic Attainment Measures}

We then proceed to examine young people's employment status, social class, and occupational status at age 25 , using information from Wave 8 . We begin by examining young people's main activity. ${ }^{2}$ This variable includes slightly different categories than the ones used for the post-16 destinations analysis due to changes in data collection. Six activity categories are provided: 1) employment, 2) unemployment, 3) education, 4) sick or disabled, 5) looking after the home or family, and 6) other. This variable therefore allows us to get a sense of the proportion of young people who are unemployed, and the proportion who are economically inactive, by looking at those who are sick/disabled or looking after the home/family. However, it is important to note that the way these categories were defined in Next Steps is not consistent with measures of unemployment/economic inactivity typically used in labour market analyses. Unlike labour market surveys that ask a series of sequential questions to determine whether respondents are unemployed, employed, or economically inactive, Next Steps measures main activities using a single question on which activity best describes what cohort members are currently doing.

\footnotetext{
${ }^{2}$ Unlike in the post-16 analysis, here we simply examine young people's activities at the time of their interview rather than calculating what their activities were at a fixed point in time. This is because at this age young people's activities are less likely to be influenced by the precise point in the year at which they were interviewed.
} 
Social class at age 25 is measured using National-Statistics Socioeconomic Classification (NS-SEC), which measures employment relations and occupational conditions. We use the 5-class version of the NS-SEC that consists of: 1) Higher managerial and professional occupations, 2) Intermediate occupations, 3) Small employers and own account workers, 4) Lower supervisor and technical occupations, 5) Semi-routine and routine occupations (Rose and Pevalin 2003).

Occupational status is measured using the Standard Occupational Classification 2010 (SOC2010). SOC2010 is a classification of occupations developed by the Office for National Statistics in collaboration with experts from the Institute for Employment Research (IER) at the University of Warwick. SOC2010 updates the earlier SOC2000 classification, and it has been designed to classify the kinds of work people do based on the typical skills required to perform different jobs (Elias and Birch 2010). Although occupational categories can span a range of skill levels, occupations near the top of the SOC2010 are generally regarded as higher-skilled than the occupations near the bottom of the classification (Elias, McKnight and Kinshott 1999).

\subsection{Other Sociodemographic Measures}

The last part of our working paper examines whether disability differentials in selected outcomes vary by gender, ethnicity, and parental social class, responding to calls for intersectional analyses in disability studies (Shifrer and Frederick 2019). For this analysis, we use measures collected in Wave 1. Gender is a binary variable (male/female). We make use of a binary ethnicity variable that distinguishes between two very broad ethnicity categories: White British; and ethnic minorities (including White Irish, Other White backgrounds, Mixed ethnicity, Indian, Pakistani, Bangladeshi, Black Caribbean, Black African, and Other ethnicities). This is because ethnic minorities represent only a small proportion of the sample and, once we separate disabled and non-disabled young people, the numbers are not sufficient to conduct meaningful analysis of separate ethnic minority groups. Parental social class is measured by the National-Statistics Socioeconomic Classification (NS-SEC). For this analysis, we use the "simplified" 3-class NS-SEC version. We follow the dominance approach, considering the highest social class reported by either parent.

\subsection{Sample Attrition and Weighting}

Wave 1 includes 12,980 (84.7 per cent) non-disabled young people, 418 (2.8 per cent) disabled young people with LSLI only, 1,105 (7.9 per cent) disabled young people with SEN but no statement, and 562 (4.6 per cent) disabled young people with a statement of need. ${ }^{3}$ Attrition in Next Steps varies by disability status, with disabled young people more likely to drop out of the survey compared to non-disabled peers. Our analysis makes use of wavespecific survey weights, which result in a largely consistent sample composition across survey waves. Table A1 (Appendix) shows counts and percentages of our 4-category disability status variable across survey waves. The small numbers in specific disability categories necessitate the use of a binary disability status (disabled/non-disabled) variable

\footnotetext{
${ }^{3}$ Counts are unweighted, percentages are weighted.
} 
for certain analyses presented in this paper. We also take account of the complex sampling design of the survey, adjusting for clustering at the school level. 


\section{Results}

\subsection{Post-16 Destinations}

We start our analysis by examining the main activities that cohort members were engaged in during November of year 12 (that is, a few months after completion of Key Stage 4). As shown in Table 1, there is a substantial disability gap in post-16 education participation: Seventy per cent of disabled young people reported education as their main activity compared to 82 per cent of non-disabled peers. Disabled young people were also more likely to be unemployed, with 9 per cent reporting unemployment as their main activity (as opposed to 4 per cent among non-disabled young people). Similarly, approximately 10 per cent of disabled young people reported employment as their main activity. There is no disability gap in employment participation at this time point. Table 1 also shows that disabled young people were more likely than non-disabled peers to have started an apprenticeship or other form of training by November of year 12 (age 16/17).

Table 1: Main activity by disability status in November of year 12 (age 16/17), weighted percentages

\begin{tabular}{lccc}
\hline & $\begin{array}{c}\text { Disabled } \\
\mathrm{n}=9,702\end{array}$ & $\begin{array}{c}\text { Not disabled } \\
\mathrm{n}=1,431\end{array}$ & $\begin{array}{c}\text { All } \\
\mathrm{n}=11,133\end{array}$ \\
\hline Education & 70.2 & 81.5 & 79.7 \\
Employment & 9.7 & 8.0 & 8.3 \\
Apprenticeship/training & 6.1 & 3.9 & 4.2 \\
Unemployment & 9.1 & 4.1 & 4.9 \\
Other & 5.0 & 2.5 & 2.9 \\
Total & 100 & 100 & 100 \\
\hline
\end{tabular}

Source: Next Steps, waves 1-4.

We now examine how these percentages change over time. Table 2 provides information on cohort members' main activities across the six time points considered in our analysis. As expected, it shows that participation in education fell steadily over time for both disabled and non-disabled cohort members. Even though the fall is no steeper for disabled young people, fewer than 40 per cent were in education by May of year 14 (when most cohort members have turned 19) as opposed to 48 per cent of non-disabled young people. This is largely a result of earlier differences in participation in post-16 education by disability status, as shown in Table 1.

At the same time, the percentage of young people who were unemployed increased substantially over time, particularly in the last time-points examined in our analysis. Table 2 shows that the increase was slightly more pronounced for disabled young people. Approximately 17 per cent of disabled young people reported unemployment as their main activity in May of year 14 (the final time-point examined in our analysis) as opposed to 8 per cent of non-disabled peers. 
Table 2: Main activity by disability status over time; weighted percentages

\begin{tabular}{|c|c|c|c|c|c|c|}
\hline \multirow[b]{3}{*}{$N$} & \multicolumn{6}{|c|}{ Disabled young people } \\
\hline & $\begin{array}{c}\text { Nov } \\
\text { year } 12\end{array}$ & $\begin{array}{l}\text { May } \\
\text { year } 12\end{array}$ & $\begin{array}{c}\text { Nov } \\
\text { year } 13\end{array}$ & $\begin{array}{c}\text { May } \\
\text { year } 13\end{array}$ & $\begin{array}{c}\text { Nov } \\
\text { year } 14\end{array}$ & $\begin{array}{c}\text { May } \\
\text { year } 14\end{array}$ \\
\hline & 1,431 & 1,432 & 1,215 & 1,221 & 1,100 & 1,104 \\
\hline Education & 70.2 & 65.6 & 60.9 & $54 \cdot 3$ & $43 \cdot 5$ & 39.5 \\
\hline Employment & 9.7 & 11.9 & 18.2 & 21.6 & 30.6 & 30.1 \\
\hline Apprenticeship/training & 6.1 & 7.4 & 7.9 & $9 \cdot 4$ & 7.2 & 7.7 \\
\hline Unemployment & 9.1 & 10.6 & 10.1 & 10.8 & 13.6 & 16.7 \\
\hline Other & 5.0 & 4.5 & 3.0 & 3.9 & 5.1 & 6.0 \\
\hline \multirow[t]{3}{*}{ Total } & 100 & 100 & 100 & 100 & 100 & 100 \\
\hline & \multicolumn{6}{|c|}{ Non-disabled young people } \\
\hline & $\begin{array}{c}\text { Nov } \\
\text { year } 12\end{array}$ & $\begin{array}{c}\text { May } \\
\text { year } 12\end{array}$ & $\begin{array}{c}\text { Nov } \\
\text { year } 13\end{array}$ & $\begin{array}{c}\text { May } \\
\text { year } 13\end{array}$ & $\begin{array}{c}\text { Nov } \\
\text { year } 14\end{array}$ & $\begin{array}{c}\text { May } \\
\text { year } 14\end{array}$ \\
\hline $\mathrm{N}$ & 9,702 & 9,713 & 8,669 & 8,673 & 8,054 & 8,039 \\
\hline Education & 81.5 & 76.9 & 66.8 & 61.4 & 51.6 & 48.1 \\
\hline Employment & 8.0 & 11.1 & 21.3 & 25.0 & 32.5 & 32.6 \\
\hline Apprenticeship/training & 3.9 & 4.7 & 6.3 & 6.8 & $5 \cdot 9$ & 6.4 \\
\hline Unemployment & 4.1 & 4.7 & 3.4 & 4.4 & 5.9 & 8.1 \\
\hline Other & 2.5 & 2.6 & 2.2 & 2.3 & 4.1 & 4.8 \\
\hline Total & 100 & 100 & 100 & 100 & 100 & 100 \\
\hline
\end{tabular}

Source: Next Steps, waves 1-6.

This is counter-balanced by an increase in the percentage of disabled young people who reported being in paid employment. Approximately 30 per cent reported paid employment as their main activity in year 14 . This not far below the equivalent percentage for non-disabled young people (33 per cent). Table 2 also shows a sharper increase in the percentage of those in paid employment between May of year 13 and November of year 14, suggesting that many disabled young people leave education two years after Key Stage 4 and enter the labour market. The same pattern can be observed among non-disabled young people, but it is slightly less pronounced.

As previously discussed, the percentage of young people in education declines steadily across the six time-points. However, it should be noted that we do not just observe a decline during the transition from one academic year to the next (e.g. from May of year 12 to November of year 13) but also declines during the same academic year. This suggests that some young people in the study dropped out of education halfway through the academic year, and while this will not always a reason for concern (for instance, if they enter employment or an apprenticeship), a large proportion of young people leaving education and moving into unemployment is a worrisome sign. To shed more light on this issue, Table 3 focuses on young people who were in education in 
November of year 12 and year 13. It shows the percentage of those who were still in education in May of year 12 and year 13, and the percentage of those who have left education for another activity.

Table 3 shows that disabled young people are somewhat more likely than non-disabled peers to leave education half-way through an academic year and, when they do so, a slightly larger proportion moves into unemployment. These differences are statistically significant $(p<0.05)$ and underscore the need to ensure that disabled young people not only make a transition to post-16 education/training, but that they are also supported to remain in education for the full academic year.

Table 3: Percentage of young people who are still in education in May of year $12 / 13$, as a percentage of all those in education in November of the relevant year, weighted percentages

\begin{tabular}{|c|c|c|c|c|c|c|}
\hline & $\begin{array}{l}\text { Disabled } \\
n=1,063\end{array}$ & $\begin{array}{c}\text { year } 12 \\
\text { Non- } \\
\text { disabled } \\
n=8,304\end{array}$ & $\begin{array}{c}\text { All } \\
\mathrm{n}=9,367\end{array}$ & $\begin{array}{c}\text { Disabled } \\
\mathrm{n}=792 \\
\end{array}$ & $\begin{array}{c}\text { year } 13 \\
\text { Non- } \\
\text { disabled } \\
n=6,274\end{array}$ & $\begin{array}{c}\text { All } \\
n=7,066\end{array}$ \\
\hline Still in education & 91.4 & 94.0 & 93.6 & 88.3 & 91.2 & 90.8 \\
\hline $\begin{array}{l}\text { No longer in education } \\
\text { Of which: }\end{array}$ & 8.6 & 6.0 & 6.4 & 11.7 & 8.8 & 9.2 \\
\hline $\begin{array}{l}\text { Employment } \\
\text { Apprenticeship/ }\end{array}$ & 2.5 & $3 \cdot 3$ & 3.2 & 5.7 & 5.7 & 5.7 \\
\hline training & 0.8 & 0.7 & 0.7 & 1.7 & 0.8 & 0.9 \\
\hline Unemployment & 4.1 & 1.3 & 1.7 & 2.6 & 1.5 & 1.6 \\
\hline Other & 1.1 & 0.7 & 0.8 & 1.6 & 0.8 & 0.9 \\
\hline Total & 100 & 100 & 100 & 100 & 100 & 100 \\
\hline
\end{tabular}

Source: Next Steps, waves 1-5.

Having provided a broad picture of disability differentials in post-16 destinations, we now examine variation between different disability groups. As explained in the Methodology section, disabled young people can be split into those who have a long-standing limiting illness or condition (LSLI) without being recognised as having special educational needs, and those who are identified as having special educational needs (either with LSLI or not). Among the latter group, a further distinction can be made between those with a statement of need and those without a statement.

Figure 1 shows the activities of these 3 groups across the six time points examined in our analysis. It is important to note that these estimates are derived from relatively small sample sizes (see Table A 1 in the Appendix). This means that, while we can infer broad patterns from this data, group percentages need to be interpreted with some caution since they are subject to relatively broad confidence intervals. 
There are notable differences between different disability categories: Participation in education is higher among the "disabled, with SEN statement" and the "disabled, LSLI only" groups than among the "disabled with SEN (no statement)" group. These differences range by five up to 12 percentage-points depending on the time point we examine. While those with statements of need are fairly likely to stay on in education after Key Stage 4 as a result of interventions like SEN transition plans, the comparatively high post-16 education participation rate among those with "LSLI only" may be partly attributed to the higher prior attainment of this group (Chatzitheochari, Parsons, and Platt 2016). As shown in Figure 1, young people who have SEN without a statement of need were the most likely to be in paid employment across all six time-points.

Figure 1: Main activities across time by broad disability groups, weighted percentages

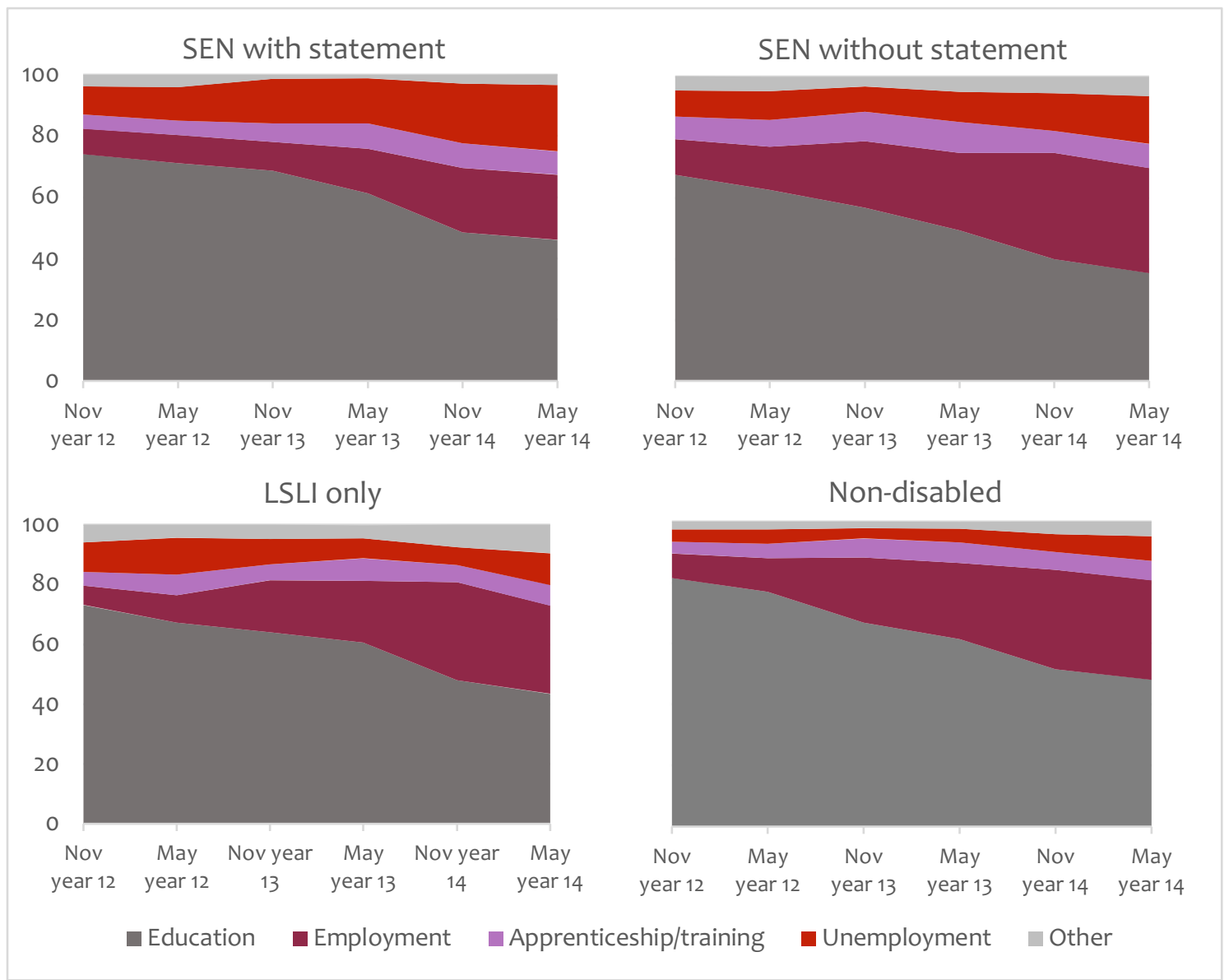

Source: Next Steps, waves 1-6.

Those with SEN statements stand out as having particularly low rates of participation in employment. In May of year 14, only 21 per cent of this group reported being in employment, suggesting that these young people find the transition into paid employment more difficult than other disability groups. The "disabled, with SEN statement" group also seems to experience unemployment at a much higher rate than the other two groups. The share of unemployed young people among this group shows a pronounced increase over time, in contrast to the two other broad disability groupings. Overall, Figure 1 shows that this group has the highest rate of participation in education, 
and the highest rates of unemployment. This suggest that regardless of interventions like SEN transitions plans, young people with SEN statements are still likely to fall into unemployment when they leave/drop out of education. These results are in line with existing evidence surrounding the higher probability to become NEET faced by SEN students (Department of Education, 2018).

While those with "LSLI only" are less likely to experience unemployment compared to the other two disability groups, they are still more likely to do so compared to their nondisabled peers. Similarly, they are less likely to stay in post-16 education compared to the non-disabled group.

\subsection{Post-16 Education Destinations}

As shown above, the vast majority of the Next Steps cohort moved into some form of education following the end of Key Stage 4. This section considers disability status differences in the type of education providers that young people move into. Sixth form colleges and school sixth forms tend to specialize in higher-level academic qualifications such as A Levels and because of this tend to be seen as being higher status than other providers. In contrast, Further Education colleges offer a wider range of qualifications. While many of these colleges also offer A Levels, they tend to specialize in vocational options.

Table 4 shows the types of education providers attended in May of year 12 by disability status. Disabled young people were much less likely to attend a school sixth form ${ }^{4}$ or sixth form college compared to their non-disabled peers. This divergence can be attributed to disability differentials in Key Stage 4 attainment (Chatzitheochari and Platt 2019). Still, Table 4 shows that 32 per cent of disabled young people in education were in schools during this time point, while 7 per cent were attending a sixth form college. The most common type of post-16 education setting for disabled young people however was a general FE college, with almost two-fifths of those in education in May of year 12 attending such an institution. This equates to more than 25 per cent of the total cohort of disabled young people at this time-point.

Table 5 shows a further breakdown of education providers by different disability categories. Out of the three groups, the "disabled, SEN with statement" group is the one least likely to be in a school sixth form or sixth form college (30 per cent and 5 per cent of those in education, respectively), and the "LSLI only" group is the most likely to be in one of these institutions ( 38 per cent and 12 per cent of those in education, respectively). Existing evidence from Next Steps suggests that these disparities between different groups may be primarily driven by differences in prior attainment (Chatzitheochari, Parsons, and Platt 2016). However, further research is needed to disentangle other

\footnotetext{
${ }^{4}$ The data only specifies whether young people are in a school or another type of provider and doesn't state specifically whether young people are in sixth form. It is therefore possible that some of these young people have been held back a year. However, this is very rare occurrence. It is also possible that some young people are in special schools, alternative provision or Pupil Referral Units. These are not distinguished from other schools in the mainstage data.
} 
factors that may be at play, including social background influences, educational plans and expectations, and/or negative experiences of disability and schooling. Such influences are frequently discussed in theoretical literature and qualitative research that focuses on the transitions of disabled adolescents, but they have not been adequately investigated using large-scale data.

Table 4: Type of education provider attended in May of year 12 by disability status, for all those in education as their main activity, weighted percentages

\begin{tabular}{lccc}
\hline & Disabled & Not disabled & \\
& $\mathrm{n}=996$ & $\mathrm{n}=7,929$ & All \\
\hline School (maintained or independent) & 31.9 & 50.0 & 47.5 \\
Sixth Form College & 7.2 & 13.4 & 12.5 \\
General FE College & 38.8 & 23.8 & 25.9 \\
Specialist College (e.g. Agricultural College) & 3.3 & 0.9 & 1.2 \\
Other incl. Academies & 9.6 & 5.4 & 6.0 \\
Unknown due to change in activity between May & & & \\
and date of interview & 6.2 & 4.9 & 5.0 \\
Unknown due to non-response & 3.0 & 1.7 & 1.9 \\
Total & 100 & 100 & 100 \\
\hline
\end{tabular}

Source: Next Steps, waves 1-4.

Table 5: Type of education provider attended in May of year 12 by disability category, for all those in education as their main activity, weighted percentages

\begin{tabular}{lccccc}
\hline & $\begin{array}{c}\text { Disabled, } \\
\text { SEN with } \\
\text { statement } \\
(\mathrm{n}=264)\end{array}$ & $\begin{array}{c}\text { Disabled, } \\
\text { SEN without } \\
\text { statement } \\
(\mathrm{n}=507)\end{array}$ & $\begin{array}{c}\text { Disabled, } \\
\text { LSLI only } \\
(\mathrm{n}=219)\end{array}$ & $\begin{array}{c}\text { Not } \\
\text { disabled } \\
(\mathrm{n}=7,929)\end{array}$ & $\begin{array}{c}\text { All } \\
(\mathrm{n}=8,919)\end{array}$ \\
\hline $\begin{array}{l}\text { School (maintained or } \\
\text { independent) }\end{array}$ & 30.2 & 30.6 & 38.2 & 50.0 & 47.5 \\
$\begin{array}{l}\text { Sixth Form College } \\
\text { General FE college }\end{array}$ & 5.4 & 6.7 & 11.6 & 13.4 & 12.5 \\
$\begin{array}{l}\text { Specialist College } \\
\text { Other incl. Academies }\end{array}$ & 42.4 & 39.2 & 31.3 & 23.8 & 25.9 \\
$\begin{array}{l}\text { Unknown due to change in } \\
\text { activity between May and }\end{array}$ & 6.4 & 2.2 & 1.6 & 0.9 & 1.2 \\
date of interview & 8.3 & 10.3 & 9.7 & 5.4 & 6.0 \\
$\begin{array}{l}\text { Unknown due to non- } \\
\text { response }\end{array}$ & 5.3 & 7.6 & 4.1 & 4.9 & 5.0 \\
Total & 1.9 & 3.5 & 3.5 & 1.7 & 1.9 \\
\hline
\end{tabular}

Source: Next Steps, waves 1-4.

These differences in type of post-16 education provider were maintained throughout year 12 and year 12. For instance, in May of year 13, only 22 per cent of disabled young people are in school sixth forms and 6 per cent are in school sixth form colleges, 
compared to 39 and 11 per cent for non-disabled young people (see Table $A 2$ in the Appendix).

Table 6 shows what type of education young people were in during May of year 14, when most Next Steps cohort members had turned 19. At this point in time, the most common education provider for disabled young people was still a general FE college, with about two-fifths of those who were still in education attending such a college. This equates to 18 per cent of all disabled young people in the cohort at this time-point, a substantially higher percentage than among non-disabled young people, 13 per cent of which were in a general FE college at this time (across the entire cohort). This partly reflects the fact that disabled young people tend to remain in further education for longer than their nondisabled peers. ${ }^{5}$ Finally, Table 6 shows that in May of year 14, about 31 per cent of disabled young people were in university, which equates to about 12 per cent of the entire disabled cohort. This is, however, far lower than the equivalent percentage of nondisabled young people, among whom 66 per cent of those in education (and 31 per cent overall) were in university.

Table 6: Type of education provider attended in May of year 14 by disability status, for all those in education as their main activity, weighted percentages

\begin{tabular}{lccc}
\hline & Not & \\
& $\begin{array}{c}\text { Disabled } \\
(\mathrm{n}=498)\end{array}$ & $\begin{array}{c}\text { disabled } \\
(\mathrm{n}=4,516)\end{array}$ & $\begin{array}{c}\text { All } \\
(\mathrm{n}=5,014)\end{array}$ \\
\hline School (maintained or independent) & 6.0 & 4.3 & 4.5 \\
Sixth Form College & 3.0 & 2.4 & 2.5 \\
General FE college & 39.6 & 19.6 & 22.2 \\
Specialist College (e.g. Agricultural College) & 2.2 & 0.7 & 0.9 \\
Other incl. Academies & 9.6 & 3.4 & 4.2 \\
University & 30.9 & 66.2 & 61.6 \\
Unknown due to change in activity between May & & & \\
and date of interview & 8.2 & 3.0 & 3.7 \\
Unknown due to non-response & 0.5 & 0.5 & 0.5 \\
Total & 100 & 100 & 100 \\
\hline
\end{tabular}

Source: Next Steps, waves 1-6.

Table 7 provides a further breakdown by broad disability groups. It shows that disabled young people with "LSLI only" are more likely to attend university compared to those young people with SEN (45 per cent as opposed to 13 per cent for those with SEN statement and 38 per cent compared to those with SEN without statement). Similarly, half of those with SEN statement are in a general Further Education college in May of year 14, as opposed to 35 per cent for those with SEN without statement and 30 per cent for those with LSLI. Overall, Table 7 reinforces our earlier findings that suggest that disabled young people with "LSLI only" are less educationally disadvantaged than the two other SEN

\footnotetext{
${ }^{5}$ Of all disabled young people, 20 per cent were observed in further education (i.e. at a general FE college, sixth form college, school sixth form or other further education provider) at all six time-points we observe, meaning they were in FE for three full academic years. This compares to just 12 per cent of non-disabled young people.
} 
groups. However, further research is needed to understand attainment-driven and other mechanisms that lead to these disparities between disability groups.

Table 7: Type of education provider attended in May of year 14 by disability category, for all those in education as their main activity, weighted percentages

\begin{tabular}{|c|c|c|c|c|c|}
\hline & $\begin{array}{l}\text { Disabled, SEN } \\
\text { with statement } \\
\quad(n=134)\end{array}$ & $\begin{array}{c}\text { Disabled, SEN } \\
\text { without statement } \\
\quad(n=248)\end{array}$ & $\begin{array}{l}\text { Disabled, } \\
\text { LSLI only } \\
(\mathrm{n}=114)\end{array}$ & $\begin{array}{c}\text { Not } \\
\text { disabled } \\
(n=4,516) \\
\end{array}$ & $\begin{array}{c}\text { All } \\
(n=5,012)\end{array}$ \\
\hline School (maintained & & & & & \\
\hline or independent) & 10.5 & 3.7 & 4.7 & $4 \cdot 3$ & $4 \cdot 5$ \\
\hline Sixth Form College & 2.2 & 3.6 & 3.0 & 2.4 & 2.5 \\
\hline General FE college & 51.4 & 35.0 & 29.8 & 19.6 & 22.2 \\
\hline $\begin{array}{l}\text { Specialist College } \\
\text { Other incl. }\end{array}$ & 2.6 & 1.8 & 2.4 & 0.7 & 0.9 \\
\hline Academies & 9.9 & 8.5 & 12.2 & 3.4 & 4.2 \\
\hline University & 12.7 & 37.8 & 44.6 & 66.2 & 61.6 \\
\hline $\begin{array}{l}\text { Unknown due to } \\
\text { change in activity } \\
\text { between May and }\end{array}$ & & & & & \\
\hline $\begin{array}{l}\text { date of interview } \\
\text { Unknown due to }\end{array}$ & 10.8 & 8.6 & 3.2 & 3.0 & 3.7 \\
\hline non-response & 0.0 & 1.0 & 0.0 & 0.5 & 0.5 \\
\hline Total & 100 & 100 & 100 & 100 & 100 \\
\hline
\end{tabular}

Source: Next Steps, waves 1-6.

\subsection{Early Socioeconomic Attainment}

We now turn our attention to early socioeconomic attainment, as captured in Wave 8 data collection. Table 8 presents the main activities of cohort members at age 25 .

At age 25, most disabled young people in Next Steps were in employment (either paid employment or self-employment $)^{6}$, but at 64 per cent, this is substantially lower than that for non-disabled young people ( 82 per cent). There also is a large disability differential in unemployment, with disabled young people more than twice as likely to be unemployed than non-disabled peers. A relatively large proportion of disabled young people also described their main activity as 'sick or disabled' or 'looking after the home or family'. Overall, these patterns are in line with well-documented disability inequalities in economic activity status during adulthood (Centre for Social Justice, 2021; Joseph Rowntree Foundation, 2005).

\footnotetext{
${ }^{6}$ These figures refer to young people who report employment as their main activity, rather than all young people who are in employment, but the percentages look very similar when including all those who report being in employment (65.4 per cent for disabled young people and 83.8 per cent for non-disabled young people).
} 
Table 8: Main activity at age 25 , by disability status

\begin{tabular}{lccc}
\hline & $\begin{array}{c}\text { Disabled } \\
(\mathrm{n}=912)\end{array}$ & $\begin{array}{c}\text { Not disabled } \\
(\mathrm{n}=6,540)\end{array}$ & $\begin{array}{c}\text { All } \\
(\mathrm{n}=7452)\end{array}$ \\
\hline Employment & 64.3 & 81.8 & 78.8 \\
Unemployment & 12.1 & 5.6 & 6.7 \\
Education & 3.6 & 4.6 & 4.5 \\
Sick or disabled & 9.3 & 1.5 & 2.8 \\
Looking after home or family & 7.4 & 5.4 & 5.7 \\
Other & 3.4 & 1.1 & 1.5 \\
Total & 100 & 100 & 100 \\
\hline
\end{tabular}

Source: Next Steps, waves 1-8.

Table 9 examines differences between our three broad disability groups. It shows that disabled young people who had a statement of need in Wave 1 were the least likely to be in employment at age 25 (at 50 per cent). There is a stark difference with the two other disability groups, which have markedly higher proportions of young people reporting employment as their main activity. Likewise, the "disabled, SEN statement" group has the highest rate of unemployment too, and the highest proportion of young people who report being sick or disabled when asked about their main activity, underscoring the difference in socioeconomic outcomes for this group of young people.

Table 9: Main activity at age 25 , for young people in different disability categories

\begin{tabular}{lccccc}
\hline & $\begin{array}{c}\text { Disabled, } \\
\text { SEN with } \\
\text { statement } \\
(\mathrm{n}=246)\end{array}$ & $\begin{array}{c}\text { Disabled, SEN } \\
\text { without statement } \\
(\mathrm{n}=460)\end{array}$ & $\begin{array}{c}\text { Disabled, } \\
\text { LSLI only } \\
(\mathrm{n}=195)\end{array}$ & $\begin{array}{c}\text { Not } \\
\text { disabled } \\
(\mathrm{n}=6,540)\end{array}$ & $\begin{array}{c}\text { All } \\
(\mathrm{n}=\end{array}$ \\
$\mathbf{7 4 4 1 )}$
\end{tabular}

Source: Next Steps, waves 1-8.

It is important to note, however, that among the two remaining disability groups, the proportion in employment is still lower than among non-disabled young people. At the same time, it is worth emphasizing that disabled young people with "LSLI only" are also characterised by relatively large rates of economic inactivity, primarily driven by a large number of cohort members that report looking after the home/family as their main 
activity. It is beyond the scope of this working paper to explain this interesting pattern specific to this disability group.

Table 10 examines social class at age 25 by disability status, using NS-SEC. It is worth noting that NS-SEC is only available for those in employment, so a substantial proportion of young people are excluded from Table 10, especially among disabled young people who, as we've seen above, are less likely to be employed at age 25. Table 10 indicates that even when they were in employment, disabled young people were more likely to be found in lower supervisory and technical occupations and semi-routine and routine occupations, and less likely to be found in higher managerial and professional occupations, compared to their non-disabled peers.

Table 10: NS-SEC ( 5 classes) at age 25 , by disability status

\begin{tabular}{lccc}
\hline & $\begin{array}{c}\text { Disabled } \\
(\mathrm{n}=638)\end{array}$ & $\begin{array}{c}\text { Not disabled } \\
(\mathrm{n}=5,429)\end{array}$ & $\begin{array}{c}\text { All } \\
(\mathrm{n}=6,067)\end{array}$ \\
\hline Higher managerial and professional & 26.9 & 45.5 & 42.7 \\
Intermediate occupations & 11.1 & 17.9 & 16.9 \\
$\begin{array}{l}\text { Small employers and own account } \\
\text { workers }\end{array}$ & 8.7 & 5.7 & 6.2 \\
Lower supervisory and technical & 12.2 & 9.7 & 10 \\
$\begin{array}{l}\text { Occupations } \\
\text { Semi-routine and routine occupations }\end{array}$ & 41.1 & 21.3 & 24.2 \\
Total & 100 & 100 & 100 \\
\hline
\end{tabular}

Source: Next Steps, waves 1-8

Table 11 break downs these results by the three broad disability categories employed in our analyses. We note that sample sizes for these categories are very small and these figures should thus be interpreted with caution. Table 11 suggests that disabled young people with statements of need in Wave 1 are over-represented in the lowest NS-SEC class. Similarly, they are also the least likely to be in a higher managerial and professional occupation. Disabled young people with SEN but without statements of need also appear relatively disadvantaged on social class attainment at age 25 . Finally, it is important to note that, even those in the "LSLI only" group, who were previously found to be the least educationally disadvantaged out of the three groups, were still more likely to be found in one of the lower NS-SEC classes (lower supervisory and technical occupations, as well as semi-routine and routine occupations) than non-disabled young people. 
Table 11: NS-SEC ( 5 classes) at age 25 , by disability category

\begin{tabular}{lccccc}
\hline & $\begin{array}{c}\text { Disabled, SEN } \\
\text { with statement } \\
(\mathrm{n}=141)\end{array}$ & $\begin{array}{c}\text { Disabled, } \\
\text { SEN without } \\
\text { statement } \\
(\mathrm{n}=350)\end{array}$ & $\begin{array}{c}\text { Disabled, } \\
\text { LSLI only } \\
(\mathrm{n}=139)\end{array}$ & $\begin{array}{c}\text { Not } \\
\text { disabled } \\
(5,429)\end{array}$ & $\begin{array}{c}\text { All } \\
(\mathrm{n}=6,059)\end{array}$ \\
\hline $\begin{array}{l}\text { Higher managerial } \\
\text { and professional } \\
\text { Intermediate }\end{array}$ & 19.8 & 27.0 & 39.0 & 45.5 & 42.8 \\
$\begin{array}{l}\text { occupations } \\
\text { Small employers }\end{array}$ & 7.2 & 11.0 & 16.1 & 17.9 & 16.9 \\
$\begin{array}{l}\text { and own account } \\
\text { workers } \\
\text { Lower supervisory }\end{array}$ & 5.5 & 11.2 & 5.9 & 5.7 & 6.2 \\
$\begin{array}{l}\text { and technical } \\
\text { occupations } \\
\text { Semi-routine and }\end{array}$ & 9.5 & 12.7 & 14.1 & 9.7 & 10.0 \\
$\begin{array}{l}\text { routine } \\
\text { occupations }\end{array}$ & 58.0 & & & & \\
\begin{tabular}{l} 
Total \\
\hline
\end{tabular} & 100 & 38.2 & 24.8 & 21.3 & 24.1 \\
\hline
\end{tabular}

Source: Next Steps, wave 1-8.

Table 12: Occupational groups of those in employment at age 25 , by disability status

\begin{tabular}{lccc}
\hline & $\begin{array}{c}\text { Disabled } \\
(\mathrm{n}=615)\end{array}$ & $\begin{array}{c}\text { Not disabled } \\
(\mathrm{n}=5,414)\end{array}$ & All \\
\hline Managers, directors and senior officials & 5.9 & 5.7 & 5.8 \\
Professional occupations & 10.9 & 20.7 & 19.3 \\
Associate professional and technical & & & \\
occupations & 10.5 & 18.5 & 17.4 \\
Administrative and secretarial occupations & 6.7 & 11.7 & 11.0 \\
Skilled trades occupations & 13.4 & 9.5 & 10.0 \\
Caring, leisure and other service occupations & 14.6 & 10 & 11.1 \\
Sales and customer service occupations & 10.3 & 11.2 & 11.0 \\
Process, plant and machine operatives & 9.2 & 4.3 & 5.0 \\
Elementary occupations & 18.6 & 7.8 & 9.3 \\
Total & 100 & 100 & 100 \\
\hline Source: & &
\end{tabular}

Source: Next Steps, waves 1-8. Occupational groups refer to SOC2010 major groups.

Further evidence of disability gaps in socioeconomic attainment can be seen in Table 12, which presents the occupational groups of those in employment at age 25. Disabled young people are under-represented in professional and associate-professional occupations, and over-represented in occupations associated with lower status and lower pay, such as caring, leisure and other service occupations; process, plant and machine operatives; and 
elementary occupations. We do not present breakdowns by disability groups on this measure due to very small sample sizes in respective categories.

Overall, descriptive analyses of Wave 8 Next Steps data reveal pronounced disability gaps in socioeconomic attainment, indicating enduring disadvantage for those who have experienced childhood/adolescent disability. These gaps in employment levels and occupational attainment raise a number of sociologically interesting questions that have not been systematically examined in previous research: More research is needed to investigate the association of post-16 educational pathways with early socioeconomic attainment for disabled young people in England, as well as qualification and skills mismatches in the labour market (Choe and Baldwin 2017; Jones and Sloane 201). Other important areas for future research are disability discrimination in hiring practices and issues surrounding reasonable adjustments at work (Eurofound 2021). At the same time, it is important to better understand the interaction of other characteristics/ascriptive inequalities with adolescent disability with respect to different socioeconomic domains. We provide an initial analysis on this matter in the next section.

\subsection{Disability Gaps by Social Class, Gender, and Ethnic Group}

We have thus far examined differences in post-16 destinations and early socioeconomic attainment by disability status and/or disability group. We now turn our attention to the interaction of disability with other social divisions, namely social class, sex, and ethnicity.

We first examine the interaction of adolescent disability with parental social class, focusing on young people's main activities in May of year 12. Table 13 shows the percentage of disabled and non-disabled young people in different main activities, contrasting those with high parental social class and those with low parental social class, denoting corresponding disability differentials (Table $A_{3}$ shows the full table of results, including those from Intermediate parental social class who have been excluded from Table 13 for space reasons).

Table 13: Disability differentials in main activities in May of year 12 by parental social class, weighted percentages

\begin{tabular}{lcccccc} 
& \multicolumn{2}{c}{ High social class (percentage in each } & \multicolumn{2}{c}{$\begin{array}{c}\text { Low social class (percentage in each } \\
\text { main activity) }\end{array}$} & \multicolumn{3}{c}{$\begin{array}{c}\text { main activity) } \\
\text { Disabled } \\
(\mathrm{n}=520)\end{array}$} & $\begin{array}{c}\text { Not disabled } \\
(\mathrm{n}=4,155)\end{array}$ & Differential & $\begin{array}{c}\text { Disabled } \\
(\mathrm{n}=520)\end{array}$ & $\begin{array}{c}\text { Not disabled } \\
(\mathrm{n}=2,785)\end{array}$ & Differential \\
\hline Education & 78.1 & 86.5 & -8.4 & 58.0 & 65.2 & -7.2 \\
Employment & 9.7 & 7.5 & 2.2 & 12.7 & 15.2 & -2.5 \\
Apprenticeship/ & & & & & & \\
training & 4.8 & 3.2 & 1.6 & 8.8 & 6.5 & 2.3 \\
Unemployment & 5.2 & 1.8 & 3.4 & 15.4 & 8.5 & 6.9 \\
Other & 2.1 & 0.9 & 1.2 & 5.1 & 4.6 & 0.5
\end{tabular}


100

100

100

100

Source: Next Steps, waves 1-4

As shown in Table 13, a smaller proportion of young people from a low parental social class background was in education in May of year 12, while a higher proportion was in employment, unemployment, and in an apprenticeship. There are fairly similar disability differentials with respect to participation in education across the two social class groups. More notable is the fact that, in contrast to those from high social class backgrounds, disabled young people from lower social class backgrounds were less likely to be in employment than non-disabled young people from the same class. To a large extent, this is explained by the higher rates of unemployment among disabled young people from a lower social class background (15 per cent as opposed to 9 per cent for non-disabled young people from the same social class).

Table 14: Disability differentials in main activities at age 25 by parental social class, weighted percentages

\begin{tabular}{|c|c|c|c|c|c|c|}
\hline & \multicolumn{3}{|c|}{$\begin{array}{l}\text { High social class (percentage in each } \\
\text { main activity) }\end{array}$} & \multicolumn{3}{|c|}{$\begin{array}{c}\text { Low social class (percentage in each } \\
\text { main activity) }\end{array}$} \\
\hline & $\begin{array}{l}\text { Disabled } \\
(n=367)\end{array}$ & $\begin{array}{c}\text { Not disabled } \\
(n=2,887)\end{array}$ & differential & $\begin{array}{l}\text { Disabled } \\
(n=305)\end{array}$ & $\begin{array}{c}\text { Not disabled } \\
(n=1,779)\end{array}$ & differential \\
\hline Employment & 78.0 & 85.9 & -7.9 & 52.0 & 75.4 & -23.4 \\
\hline Unemployment & 7.1 & 3.7 & 3.4 & 15.1 & 8.8 & 6.3 \\
\hline Education & 3.3 & 5.4 & -2.1 & 4.6 & 3.4 & 1.2 \\
\hline $\begin{array}{l}\text { Sick or disabled } \\
\text { Looking after }\end{array}$ & 5.6 & 0.8 & 4.8 & 15.6 & 2.4 & 13.2 \\
\hline home or family & 2.9 & 3.1 & -0.2 & $9 \cdot 4$ & 9.2 & 0.2 \\
\hline Other & 3.2 & 1.0 & 2.2 & 3.4 & 0.9 & 2.5 \\
\hline Total & 100 & 100 & & 100 & 100 & \\
\hline
\end{tabular}

Source: Next Steps, wave 1-8.

Table 14 examines main activity at age 25 (see Table A4 for full results). We can see that disability differentials vary substantially by parental social class background. There is a pronounced difference between those with lower and higher parental class with regards to employment participation ( 23 percentage points between disabled and non-disabled young people from a lower social class background as opposed to 8 percentage points between those from a higher social class background). Pronounced differences can also be seen for unemployment as well as sickness/disability reported as main activity. These patterns suggest that disability may have a disproportionate effect on young people experiencing social class disadvantage with respect to economic activity in early adulthood. Further research is needed to ascertain the mechanisms behind these patterns. 
Tables 15 and 16 examine disability differentials by gender. Table 15 suggests that gender might mediate the impact of disability on post-16 education participation, as evidenced by the pronounced differences in the disability differentials for young men and young women. There are also differences with respect to employment participation. Disabled young men are slightly more likely than their non-disabled peers to be in paid employment, whereas disabled girls are less likely than non-disabled girls to do so. These patterns may reflect gendered differences in Key Stage 4 attainment, as well as better structures in place to support young males into employment.

Table 15: Disability differentials in main activities in May of year 12, by gender

\begin{tabular}{|c|c|c|c|c|c|c|}
\hline & \multicolumn{3}{|c|}{ Male } & \multicolumn{3}{|c|}{ Female } \\
\hline & $\begin{array}{l}\text { Disabled } \\
(n=845)\end{array}$ & $\begin{array}{c}\text { Not } \\
\text { disabled } \\
(n= \\
4,742)\end{array}$ & differential & $\begin{array}{c}\text { Disabled } \\
\qquad(\mathrm{n}= \\
584)\end{array}$ & $\begin{array}{c}\text { Not } \\
\text { disabled } \\
(n= \\
4,964)\end{array}$ & differential \\
\hline Education & 59.4 & 74.0 & -14.6 & 74.6 & 79.7 & -5.1 \\
\hline Employment & $15 \cdot 5$ & 12.6 & 2.9 & 6.5 & 9.7 & -3.2 \\
\hline Apprenticeship/training & 8.8 & 6.0 & 2.8 & $5 \cdot 3$ & 3.4 & 1.9 \\
\hline Unemployment & 12.5 & $5 \cdot 3$ & 7.2 & 8.1 & 4.1 & 4.0 \\
\hline Other & 3.8 & 2.1 & 1.7 & $5 \cdot 5$ & 3.1 & 2.4 \\
\hline Total & 100 & 100 & 100 & 100 & 100 & 100 \\
\hline
\end{tabular}

Source: Next Steps, waves 1-4.

Table 16: Disability differentials in main activities at age 25 , by gender

\begin{tabular}{lcccccc}
\hline & $\begin{array}{c}\text { Disabled } \\
(\mathrm{n}=492)\end{array}$ & $\begin{array}{c}\text { Not disabled } \\
(\mathrm{n}=2,808)\end{array}$ & differential & $\begin{array}{c}\text { Disabled } \\
(\mathrm{n}=412)\end{array}$ & $\begin{array}{c}\text { Fot disabled } \\
(\mathrm{n}=3,712)\end{array}$ & differential \\
\hline Employment & 67.4 & 85.9 & -18.5 & 59.1 & 77.9 & -18.8 \\
Unemployment & 15.0 & 6.1 & 8.9 & 7.6 & 5.0 & 2.6 \\
Education & 2.7 & 4.4 & -1.7 & 4.9 & 4.9 & 0.0 \\
Sick or disabled & 11.0 & 1.7 & 9.3 & 6.6 & 1.3 & 5.3 \\
Looking after & & & & & & \\
home or family & 0.5 & 0.8 & -0.3 & 18.2 & 9.7 & 8.5 \\
Other & 3.4 & 1.1 & 2.3 & 3.5 & 1.2 & 2.3 \\
& & & & & & 100 \\
Total & 100 & 100 & 100 & 100 & 100 & 100 \\
\hline
\end{tabular}

Source: Next Steps, waves 1-8.

The contrast between genders becomes less pronounced at age 25. Disability gaps in employment participation (as main activity) do not vary by gender (Table 16). However, differentials in unemployment are more severe for men. In contrast, a large gap is found 
for women when it comes to those who report looking after the home or family as their main activity: 18 percent of disabled young women report being at home/looking after the family as their main activity as opposed to 9 percent of non-disabled young women.

The remaining part of this section examines ethnicity. Table 17 shows disability gaps in main activities in May of year 12 by two broad ethnic groups: White British and ethnic minorities. We can see that the proportion of young people remaining in education in May of year 12 is markedly higher among both disabled and non-disabled young people belonging to ethnic minorities compared to those of White British ethnicity. However, the differential between the disabled and non-disabled groups is very similar across the two broad ethnic groups. In contrast, the disability differential in unemployment is substantially larger for young people from a white British ethnic background than for those from a minority ethnic background.

Table 17: Disability differentials in main activities in May of year 12, by broad ethnic group

\begin{tabular}{|c|c|c|c|c|c|c|}
\hline & \multicolumn{3}{|c|}{ White British } & \multicolumn{3}{|c|}{ Ethnic minorities } \\
\hline & $\begin{array}{c}\text { Disabled }(\mathrm{n} \\
=1,153)\end{array}$ & $\begin{array}{c}\text { Not disabled } \\
(n=6,483)\end{array}$ & differential & $\begin{array}{l}\text { Disabled } \\
(n=276)\end{array}$ & $\begin{array}{l}\text { Not disabled } \\
(n=3,222)\end{array}$ & differential \\
\hline Education & 64.2 & 74.6 & -10.4 & 79.6 & 89.4 & -9.8 \\
\hline Employment & 12.8 & 12.5 & 0.3 & 2.3 & 3.5 & -1.2 \\
\hline $\begin{array}{l}\text { Apprenticeship/ } \\
\text { training }\end{array}$ & 7.4 & 5.1 & 2.3 & 6.7 & 2.2 & 4.5 \\
\hline Unemployment & 11.1 & 4.9 & 6.2 & 5.9 & $3 \cdot 3$ & 2.6 \\
\hline Other & 4.4 & 2.8 & 1.6 & 5.4 & 1.6 & 3.8 \\
\hline Total & 100 & 100 & 100 & 100 & 100 & 100 \\
\hline
\end{tabular}

Source: Next Steps, waves 1-4.

Table 18: Disability differentials in main activities at age 25 , by broad ethnic group White British Ethnic minorities

\begin{tabular}{lcccccc} 
& $\begin{array}{c}\text { Disabled } \\
(\mathrm{n}=709)\end{array}$ & $\begin{array}{c}\text { Not disabled } \\
(\mathrm{n}=4,380)\end{array}$ & differential & $\begin{array}{c}\text { Disabled } \\
(\mathrm{n}=195)\end{array}$ & $\begin{array}{c}\text { Not disabled } \\
(\mathrm{n}=2,139)\end{array}$ & differential \\
\hline Employment & 64.6 & 82.9 & -18.3 & 60.6 & 76.5 & -15.9 \\
Unemployment & 11.5 & 4.9 & 6.6 & 17.1 & 8.8 & 8.3 \\
Education & 3.2 & 4.1 & -0.9 & 6.7 & 7.5 & -0.8 \\
Sick or disabled & 9.9 & 1.6 & 8.3 & 3.9 & 0.9 & 3.0 \\
Looking after & & & & & & \\
home or family & 7.6 & 5.6 & 2.0 & 5.9 & 4.1 & 1.8 \\
Other & 3.2 & 0.9 & 2.3 & 5.7 & 2.1 & 3.6 \\
& & & & & & 100 \\
Total & 100 & 100 & 100 & 100 & 100 & \\
\hline
\end{tabular}

Source: Next Steps, waves 1-8.

At age 25, young people from ethnic minority backgrounds remained more likely than their White British counterparts to be in education, and this was the case across both 
disabled and non-disabled young people (see Table 18). Interestingly, at age 25, the overall proportion of young people who were unemployed was marginally higher among those from ethnic minorities, unlike in year 12 (age 17). Similarly, the differential between disabled and non-disabled young people with regards to unemployment is also slightly higher among the minority ethnic category. Although more research is needed to investigate the processes at work, these results may imply that, as young people move from the education system and enter the labour market, those from ethnic minorities are no longer protected from unemployment to the same degree, leading to a steep increase in the rate of unemployment among both non-disabled and, particularly, disabled young people from an ethnic minority background. This finding needs to be evaluated against the higher proportion of White British young people who report being sick or disabled at this age compared to ethnic minorities, and the substantially higher disability differential found among the White British group when it comes to being sick or disabled as a main activity. 


\section{Concluding Remarks}

This working paper analysed data from Next Steps in order to provide an exploratory analysis of post-16 destinations and early socioeconomic outcomes of disabled young people. Our analyses highlight disability differentials in post-16 destinations, with disabled cohort members more likely to experience unemployment and less likely to continue in post-compulsory education than their non-disabled peers. There are also inequalities in education providers among those who continue in education: Disabled young people are less likely to be in providers associated with "academic" routes and more likely to continue in general Further Education colleges. Disability disparities become even more pronounced at age 25 . Our examination of cohort members' main activities at that time point revealed very pronounced gaps in employment and unemployment levels.

We also examined variation by three broad disability groups. This analysis revealed considerable differences with respect to educational pathways as well as early socioeconomic attainment: Cohort members with a statement of need emerged as a particularly vulnerable group, which is line with existing evidence from the SEN literature. We also presented some preliminary evidence on the relative educational advantage of the "LSLI only" group compared to SEN groups, with a relatively high proportion of young people from this group moving into sixth form and then university (though still considerably lower compared to their non-disabled peers). At the same time, at age $25 \mathrm{a}$ substantial proportion of young people in the "LSLI only" group appear to be economically inactive, almost as high as among young people who in wave 1 had a statement of SEN. These findings suggest that young people with long-standing limiting conditions but without a formal identification of special educational needs are characterised by a relatively wide variability in pathways and outcomes, some of them having successful academic transitions and moving into employment, and some experiencing more problematic trajectories. Future research could examine the extent to which some of these problematic trajectories can be attributed to health problems arising from longstanding conditions and to social barriers preventing disabled young people from fulfilling their potential.

Finally, we showed that disability differentials vary by social class, gender, and ethnicity. For instance, disability appears to have a higher impact for young men with regards to continuing in education after Key Stage 4 than for young women. The effect of disability also appears to take different expressions across White British and ethnic minority young people. Additionally, we presented findings which suggest that when it comes to economic activity in early adulthood, disability may have a disproportionate effect on young people from lower social class backgrounds. This preliminary analysis reinforces previous calls about the importance of intersectional analyses in disability research.

As highlighted by our research, survey attrition and the resulting small samples of disabled young people in later waves means that researchers are not able to distinguish between different groups of disabilities when focusing on later life outcomes. A lot of interesting research questions surrounding different groups of conditions and their association with various life outcomes therefore cannot be answered using this cohort study: For example, 
it is not possible to document differences in outcomes between young people with physical, socioemotional, and cognitive disabilities, which are subject to different structural and cultural "ableisms" (Campbell 2009) and can have different implications for life-course transitions and trajectories. Regardless of this limitation, longitudinal data are necessary for the more generalised purpose of highlighting disability trajectories of disadvantage and variation by key contextual factors (Altman 2014). To this end, Next Steps offers a wide range of measures that can be used to better understand processes behind some of the patterns of inequality underlined in this working paper. Linked attainment data from the National Pupil Database can be used to understand the impact of prior attainment on post-16 destinations, while a wide range of school and family related variables can capture important factors such as educational aspirations, peer group influences, school and learning experiences, and bullying victimisation.

In this paper, we have attempted to demonstrate some of the potential of Next Steps in helping to gain a better understanding of the varied post- 16 trajectories of disabled young people, as well as their early socioeconomic outcomes at age 25 . We hope that the findings presented here will inspire further research into the experiences of disabled young people in early adulthood, and how these interact with gender, ethnicity and social class. 


\section{References}

Altman, B. (2014) Definitions, Concepts, and Measures of Disability, Annals of Epidemiology, 24(1):2-7

Blackburn, C., Spencer, N.J. and Read, J.M. (2010) Prevalence of Childhood Disability and the Characteristics and Circumstances of Disabled Children in the UK: Secondary Analysis of the Family Resources Survey, BMC Pediatrics, 10(1): 21

Centre for Social Justice (2021) Now is the Time: A Report by the Disability Commission. London: The Centre for Social Justice

Champaloux, S., and Young, D. (2015) Childhood Chronic Health Conditions and Educational Attainment: A Social Ecological Approach, Journal of Adolescent Health, 56(1): 98-105

Chatzitheochari, S., and Platt, L. (2019) Disability Differentials in Educational Attainment in England: Primary and Secondary Effects, British Journal of Sociology, 70(2):502-525

Chatzitheochari, S., Parsons, S. and Platt, L. (2016) Doubly Disadvantaged? Bullying Experiences among Children and Young People in England, Sociology, 50(4): 695- 713

Choe, C. \& Baldwin, M. (2017) Duration of disability, job mismatch and employment outcomes, Applied Economics, 49(10): 1001-1015

Crawford, C. and Vignoles, A. (2010) An Analysis of the Educational Progress of Children with Special Educational Needs, DoQSS Working Paper 10-19. Department of Quantitative Social Science - UCL Institute of Education, University College London

Crump, C., Rivera, D., London, R., Landau, M., Erlendson, B. and Rodriguez, E. (2013) Chronic Health Conditions and School Performance among Children and Youth, Annals of Epidemiology, 23(4): 179-84

Department of Education (2018) Characteristics of Young People who are Long-Term NEET. London: Department of Education

Dickerson, A., Morris, D., and McDool, E. (2020) Post Compulsory Education Pathways and Labour Market Outcomes. Centre for Vocational Research Paper. London School of Economics and Political Science

Elias, P. and Birch, M. (2010) SOC2010: revision of the Standard Occupational Classification, Economic \& Labour Market Review, 4(7): 48-55

Elias, P., McKnight, A. and Kinshott, G. (1999) SOC 2000 - Redefining Skill: Revision of the Standard Occupational Classification, Skills Task Force Research Paper 19, Sheffield: Department for Education and Employment 
Eurofound (2021) Disability and Labour Market Integration: Policy Trends and Support in EU Member States. Publication Office of the European Union: Luxembourg

Gayle, V., Murray, S., and Connelly, R. (2014) Young People and School Certificate of Secondary Education Attainment: Looking for the "Missing Middle", British Journal of Sociology of Education, 37(3): 350-370

Halfon, N., Houtrow, A., Larson, K. and Newacheck, P. (2012) The Changing Landscape of Disability in Childhood, The Future of Children, 22(1):13-42

Holt L (2004) Childhood disability and ability: (Dis)ableist geographies of mainstream primary schools. Disability Studies Quarterly 24(3): 20-48.

Janus, A.L. (2009) Disability and the Transition to Adulthood, Social Forces, 88(1):99-120

Jenkins, R. (1991) Disability and Social Stratification, British Journal of Sociology, 42(4):557580

Jones, M. \& Sloane, P. (2010) Disability and Skills Mismatch, Economic Record, 86(1): 101114

Joseph Rowntree Foundation (2005) The Education and Employment of Disabled Young People. York: Joseph Rowntree Foundation

Liasidou, A. (2013) Intersectional Understandings of Disability and Implications for a Social Justice Reform Agenda in Education Policy and Practice, Disability \& Society, 28(3): 299-312

Parsons, S. and Platt, L. (2020) The Social Relationships of Three Generations Identified as Disabled in Childhood, Longitudinal and Life Course Studies, 11(4): 519-550

Parsons, S. and Platt, L. (2017) The Early Academic Progress of Children with Special Educational Needs, British Educational Research Journal, 43(3): 466-85

Powell, J. (2006) Special Education and the Risk of Becoming Less Educated, European Societies 8(4): 577-99

Powell, J. (2003) Constructing Disability and Social Inequality Early in the Life Course: The Case of Special Education in Germany and the United States, Disability Studies Quarterly, 23(2):57-75

Rose, D, and Pevalin, D. (2003) A Researcher's Guide to the National Statistics Socioeconomic Classification, London: Sage.

Shandra, C.L. and Hogan, D. (2009) The Educational Attainment Process Among Adolescents with Disabilities And Children of Parents with Disabilities, International Journal of Disability, Development and Education, 56(4):363-379 
Shifrer, D. and Mackin Freeman, D. (2021) Problematizing Perceptions of STEM Potential: Differences by Cognitive Disability Status in High School and Postsecondary Educational Outcomes, Socius, 7: 1-13

Shifrer, D., and Frederick, A. (2019) Disability at the Intersections, Sociology Compass, 13(10)

Shifrer, D. (2013) 'Stigma of a Label Educational Expectations for High School Students Labeled with Learning Disabilities', Journal of Health and Social Behavior, 54(4): 462-80

Tomlinson, S. (2017) A Sociology of Special and Inclusive Education, Routledge

University College London, UCL Institute of Education, Centre for Longitudinal Studies (2021) Next Steps: Sweeps 1-8, 2004-2016 [data collection]. $15^{\text {th }}$ Edition. UK Data Service. 


\section{Appendix}

Table A1: Weighted percentage of young people in each disability category, by wave (unweighted counts in brackets)

\begin{tabular}{lrrrrr}
\hline & $\begin{array}{r}\text { Disabled, SEN } \\
\text { with statement }\end{array}$ & $\begin{array}{r}\text { Disabled, SEN } \\
\text { without statement }\end{array}$ & $\begin{array}{r}\text { Disabled, LSLI } \\
\text { only }\end{array}$ & Not disabled & All \\
\hline wave 1 & $4.6(\mathrm{~N}=562)$ & $7.9(\mathrm{~N}=1,015)$ & $2.8(\mathrm{~N}=418)$ & $84.7(\mathrm{~N}=12,980)$ & $100(\mathrm{~N}=14,975)$ \\
wave 2 & $4.6(\mathrm{~N}=470)$ & $8.5(\mathrm{~N}=954)$ & $2.8(\mathrm{~N}=364)$ & $84.1(\mathrm{~N}=11,627)$ & $100(\mathrm{~N}=13,415)$ \\
wave 3 & $4.6(\mathrm{~N}=413)$ & $8.5(\mathrm{~N}=866)$ & $2.8(\mathrm{~N}=327)$ & $84.1(\mathrm{~N}=10,725)$ & $100(\mathrm{~N}=12,331)$ \\
wave 4 & $4.5(\mathrm{~N}=367)$ & $8.5(\mathrm{~N}=790)$ & $2.9(\mathrm{~N}=304)$ & $84.2(\mathrm{~N}=9,891)$ & $100(\mathrm{~N}=11,352)$ \\
wave 5 & $4.3(\mathrm{~N}=316)$ & $8.2(\mathrm{~N}=675)$ & $2.9(\mathrm{~N}=265)$ & $84.7(\mathrm{~N}=8,854)$ & $100(\mathrm{~N}=10,110)$ \\
wave 6 & $4.5(\mathrm{~N}=293)$ & $8.2(\mathrm{~N}=625)$ & $2.8(\mathrm{~N}=245)$ & $84.4(\mathrm{~N}=8,315)$ & $100(\mathrm{~N}=9,478)$ \\
wave 7 & $4.3(\mathrm{~N}=252)$ & $8.2(\mathrm{~N}=540)$ & $2.9(\mathrm{~N}=218)$ & $84.5(\mathrm{~N}=7,419)$ & $100(\mathrm{~N}=8,429)$ \\
wave 8 & $5.4(\mathrm{~N}=248)$ & $8.8(\mathrm{~N}=464)$ & $2.9(\mathrm{~N}=199)$ & $82.9(\mathrm{~N}=6,565)$ & $100(\mathrm{~N}=7,476)$ \\
\hline
\end{tabular}

Source: Next Steps, waves 1-8.

Table A2: Type of education provider attended in May of year 13, for all those in education as their main activity by disability status

\begin{tabular}{|c|c|c|c|}
\hline & \multicolumn{3}{|c|}{ Not } \\
\hline & $\begin{array}{c}\text { Disabled } \\
(n=712)\end{array}$ & $\begin{array}{c}\text { disabled } \\
(n=5,829)\end{array}$ & $\begin{array}{c}\text { All } \\
(n=6,541)\end{array}$ \\
\hline School (maintained or independent) & 21.9 & 39.1 & 36.7 \\
\hline Sixth Form College & 6.2 & 10.9 & 10.3 \\
\hline General FE college & 37.9 & 26.1 & 27.7 \\
\hline Specialist College & 2.1 & 1.0 & 1.1 \\
\hline Other incl. Academies & 15.2 & 9.7 & 10.4 \\
\hline $\begin{array}{l}\text { Unknown due to change in activity between May and } \\
\text { date of interview }\end{array}$ & 16.3 & 12.8 & 13.3 \\
\hline Unknown due to non-response & 0.4 & 0.5 & 0.5 \\
\hline Total & 100 & 100 & 100 \\
\hline
\end{tabular}

Source: Next Steps, waves 1-5. 
Table A3: Disability differentials in main activities in May of year 12, by parental social class

\begin{tabular}{|c|c|c|c|c|c|c|c|c|c|}
\hline & \multicolumn{3}{|c|}{$\begin{array}{c}\text { High social class (percentage in each } \\
\text { main activity) }\end{array}$} & \multicolumn{3}{|c|}{$\begin{array}{c}\text { Intermediate social class (percentage in } \\
\text { each main activity) }\end{array}$} & \multicolumn{3}{|c|}{$\begin{array}{c}\text { Low social class (percentage in each } \\
\text { main activity) }\end{array}$} \\
\hline & $\begin{array}{l}\text { Disabled } \\
(n=520)\end{array}$ & $\begin{array}{l}\text { Not disabled } \\
(n=4,155)\end{array}$ & differential & $\begin{array}{l}\text { Disabled } \\
(n=295)\end{array}$ & $\begin{array}{l}\text { Not disabled } \\
(\mathrm{n}=2,034)\end{array}$ & differential & $\begin{array}{l}\text { Disabled } \\
(\mathrm{n}=520)\end{array}$ & $\begin{array}{l}\text { Not disabled } \\
(\mathrm{n}=2,785)\end{array}$ & differential \\
\hline Education & 78.1 & 86.5 & -8.4 & 65.2 & 77.8 & -12.6 & 58.0 & 65.2 & -7.2 \\
\hline Employment & 9.7 & 7.5 & 2.2 & 14.0 & 12.2 & 1.8 & 12.7 & 15.2 & -2.5 \\
\hline $\begin{array}{l}\text { Apprenticeship/ } \\
\text { training }\end{array}$ & 4.8 & 3.2 & 1.6 & 9.0 & 5.4 & 3.6 & 8.8 & 6.5 & 2.3 \\
\hline Unemployment & 5.2 & 1.8 & 3.4 & 6.9 & 3.4 & 3.5 & 15.4 & 8.5 & 6.9 \\
\hline Other & 2.1 & 0.9 & 1.2 & 4.9 & 1.2 & 3.7 & 5.1 & 4.6 & 0.5 \\
\hline Total & 100 & 100 & & 100 & 100 & & 100 & 100 & \\
\hline
\end{tabular}

Source: Next Steps, wave 1-4.

Table A4: Disability differentials in main activities at age 25 , by parental social class

\begin{tabular}{|c|c|c|c|c|c|c|c|c|c|}
\hline & \multicolumn{3}{|c|}{$\begin{array}{l}\text { High social class (percentage in each main } \\
\text { activity) }\end{array}$} & \multicolumn{3}{|c|}{$\begin{array}{l}\text { Intermediate social class (percentage } \\
\text { in each main activity) }\end{array}$} & \multicolumn{3}{|c|}{$\begin{array}{l}\text { Low social class (percentage in each } \\
\text { main activity) }\end{array}$} \\
\hline & $\begin{array}{l}\text { Disabled } \\
(\mathrm{n}=367)\end{array}$ & $\begin{array}{c}\text { Not disabled } \\
(n=2,887)\end{array}$ & differential & $\begin{array}{l}\text { Disabled } \\
(n=185)\end{array}$ & $\begin{array}{l}\text { Not disabled } \\
(n=1,402)\end{array}$ & differential & $\begin{array}{l}\text { Disabled } \\
(\mathrm{n}=305)\end{array}$ & $\begin{array}{l}\text { Not disabled } \\
(n=1,779)\end{array}$ & differential \\
\hline Employment & 78.0 & 85.9 & -7.9 & 72.8 & 85.5 & -12.7 & 52.0 & 75.4 & -23.4 \\
\hline Unemployment & 7.1 & 3.7 & 3.4 & 10.6 & 3.6 & 7.0 & 15.1 & 8.8 & 6.3 \\
\hline Education & 3.3 & 5.4 & -2.1 & 2.6 & 4.7 & -2.1 & 4.6 & 3.4 & 1.2 \\
\hline Sick or disabled & 5.6 & 0.8 & 4.8 & 2.8 & 0.9 & 1.9 & 15.6 & 2.4 & 13.2 \\
\hline $\begin{array}{l}\text { Looking after home } \\
\text { or family }\end{array}$ & 2.9 & & -0.2 & 9.6 & & & & & \\
\hline Other & 3.2 & $\begin{array}{l}3.1 \\
1.0\end{array}$ & 2.2 & $\begin{array}{l}9.0 \\
1.6\end{array}$ & $\begin{array}{l}3.1 \\
1.6\end{array}$ & $\begin{array}{l}5 \cdot 9 \\
0.0\end{array}$ & $\begin{array}{l}9.4 \\
3.4\end{array}$ & $\begin{array}{l}9.2 \\
0.9\end{array}$ & $\begin{array}{l}0.2 \\
2.5\end{array}$ \\
\hline Total & 100 & 100 & & 100 & 100 & & 100 & 100 & \\
\hline
\end{tabular}

Source: Next Steps, wave 1-8. 
